cations therefore reflect variability in the EASM and IOSM respectively.

\section{Global connections of the Asian monsoon recorded in peat}

Comparison of the Hani and Hongyuan $\delta^{13} \mathrm{C}$ records has revealed the phenomenon of antiphase variations between the EASM and IOSM on centennial to millennial timescales (Fig. 2). Abrupt strengthening of the EASM and simultaneous abrupt weakening of the IOSM appear to have occurred at times that correspond to the nine abrupt ice-rafted debris events in the North Atlantic (Hong et al., 2003, 2005), suggesting global teleconnections between the North Atlantic, Pacific Ocean and monsoon systems throughout the Holocene. The anti-phase variations of the two Asian monsoons correspond to both reduced solar activity in the late Holocene and to meltwater events in the early Holocene. A conceptual model of global climate changes that summarizes the connections between ice sheet variations at high northern latitudes, oceanatmospheric process of the equatorial Pacific, monsoonal activity in the middlelow latitudes, and solar activity is shown in Figure 3. It remains for these interactive processes to be further examined and tested against new paleoclimate records. Peat cellulose isotope indicators could play an important role in this investigation because nearly all land regions affected by the processes mentioned above possess peatlands. A systematic global comparative study on peatland paleoclimatology would help test our hypotheses of monsoon variability as well as addressing other key paleoclimate questions (see e.g., Booth et al., this issue).

\section{References}

Hong, Y.T., Wang, Z.G., Jiang, H.B., Lin, Q.H., Hong, B., Zhu, Y.X., Wang, Y., XU, L.S., Leng, X.T. and Li, H.D., 2001: A 6000-year record of changes in drought and precipitation in northeastern China based on a $\delta^{13} \mathrm{C}$ time series from peat cellulose, Earth and Planetary Science Letters, 185: 111-119.

Briggs, D.E.G., Evershed, R.P. and Lockheart, M.J., 2000: The biomolecular paleontology of continental fossils, Paleobiology, 26: 169-193.

Hong, B., Lin, Q.H. and Hong, Y.T., 2006: Interconnections between the Asian monsoon, ENSO, and high northern latitude climate during the Holocene, Chinese Science Bulletin, 51: 11-19.

Sun, S. and Yin, M., 1999: Subtropical high anomalies over the Western Pacific and its relations to the Asian monsoon and SST anomaly, Advances in Atmospheric Sciences, 16: 559-568.

Hong, Y.T., Hong, B., Lin, Q.H., Shibata, Y., Zhu, Y.X., Leng, X.T. and Wang Y., 2009: Synchronous climate anomalies in the western North Pacific and North Atlantic regions during the last 14,000 years, Quaternary Science Reviews, 28: 840-849.

\title{
Peat as an archive of atmospheric pollution and environmental change: A case study of lead in Europe
}

\author{
François De Vleeschouwer ${ }^{1}$, G. Le Roux ${ }^{2}$ and W. Shotyk ${ }^{3}$ \\ 'Department of Ecology and Environmental Science, Umeå University, Sweden; francois.devleeschouwer@emg.umu.se \\ ${ }^{2}$ EcoLab (UMR 5245), National Center for Scientific Research, Université de Toulouse, France; ${ }^{3}$ Environmental Inorganic and Isotope Geochemis- \\ try Research Group, Institute of Earth Sciences, University of Heidelberg, Germany
}

\section{Inorganic geochemistry in peat deposits provides unique and valuable indications of human activities and consequent environmental changes.}

\section{European heavy metal pollution}

Ombrotrophic bogs are uniquely suited to provide records of natural and anthropogenic airborne particles because their surface layers are exclusively fed by atmospheric inputs (i.e., rain, snow, fog, dust), and hence offer the unique possibility to record atmospheric metal emissions at a relatively high time-resolution (centennial to decadal). Peat cores from such bogs are excellent continental archives of atmospheric lead $(\mathrm{Pb})$ deposition not only because they receive $\mathrm{Pb}$ solely from the air but also because they efficiently retain this metal despite their low pore-water $\mathrm{pH}$ (c. 4) and the seasonal variations in redox potential that should promote particle dissolution (e.g., Shotyk and Le Roux, 2005, and references therein). The high abundance of natural complex-forming organic acids guarantees the preservation of metal-bearing particles, especially lead.

It is of particular importance to document both background and actual metal fluxes because the atmospheric geochemical cycle of lead and other metals has been profoundly affected by human activities throughout the Northern Hemisphere for more than 3 ka (Nriagu, 1983). Human activities have significantly impacted the atmospheric emissions of a broad range of metals and metalloids (e.g., $\mathrm{Pb}$, copper $(\mathrm{Cu})$, zinc, cadmium, mercury $(\mathrm{Hg})$ ), as a result of the smelting of metal sulfide ores and the combustion of coal, both releasing particulates and aerosols (Pacyna et al., 2007, 2009). Given the ease by which it can be smelted and the number of possible industrial and commercial applications, $\mathrm{Pb}$ has been used by humans for more than 8 ka (Wertime, 1973). In addition, the stable isotopes of $\mathrm{Pb}$ allow "natural" $\mathrm{Pb}$ to be distinguished from various anthropogenic sources (lead ores, coal, gasoline), allowing one to track pollution sources and tackle the origin of long-range natural dust contributions during the Holocene.

Long-term $\mathrm{Pb}$ emissions over Europe have been unambiguously documented by analysis of peat cores from ombrotrophic bogs (e.g., Shotyk et al., 1998). Using $\mathrm{Pb}$ isotopes, Kylander et al. (2005) in Spain and Shotyk et al. (1998) in Switzerland have also shown significant variability in Saharan dust input over Europe during the Holocene. From a paleotoxicity point of view, the pre-anthropogenic emissions of $\mathrm{Pb}$-bearing particles are insignificant compared to late Holocene anthropogenic emissions. Moreover, their larger grain size (5-50 $\mu \mathrm{m}$ compared to $0.5 \mu \mathrm{m}$ for anthropogenic particles) and low solubility in natural conditions render them largely harmless for the environment and humans (Shotyk and Le Roux, 2005). The anthropogenic lead-bearing particles, due to their sub-micronic grain size, are easily incorporated in the environment and also in human beings by inhalation or ingestion. In addition, the amount emitted in the atmosphere, although fluctuating with climate and therefore representing a potential tracer for Holocene paleoclimatic changes, is negligible compared to the amount of anthropogenic lead-bearing particles emitted during the second half of the Holocene.

Geological archives are commonly employed to assess the extent of metal release to the environment, including the atmospheric fluxes and other predominant sources. During the past 50 years, bogs have become increasingly recognized as the best continental archives of atmospheric $\mathrm{Pb}$ deposition, especially in Europe (Fig. 1), a region that has contributed so much to global atmospheric pollution. A number of European bogs have yielded high-resolution reconstructions of atmospheric $\mathrm{Pb}$ deposition (e.g., Shotyk et al., 1998; Le Roux et al., 2004; De Vleeschouwer et al., 2009, and references 
therein). Since the last decade, there has been growing interest in: (1) the reconstruction of $\mathrm{Pb}$ inventories within and between regions, (2) the use of $\mathrm{Pb}$ and other trace elements to help solve archeological problems pertaining to archeometallurgy, and (3) the combination of palynological and geochemical studies to investigate human-environment relationship in mining areas (Jouffroy-Bapicot et al., 2007). In the first case, to better constrain pollutant inventories, it is necessary to first determine the pre-anthropogenic deposition rate of these compounds, and assess their natural variation in space and time (e.g., Kylander et al., 2005; Shotyk et al., 2001). In the second and the third cases, peat records offer the unique opportunity to provide a detailed, reliable chronology of metal pollution where archeological and/ or historical evidences are lacking (e.g., Mighall et al., 2009; Renson et al., 2008).

Studies on European bogs have yielded records of $\mathrm{Pb}$ contamination varying in intensity that are consistent with the known history of lead sulfide mining (Fig. 1). Isotopic studies covering the beginning of early metallurgy show local- to regional-scale $\mathrm{Pb}$ pollution (e.g., Baron et al., 2005; Cloy et al., 2005; Le Roux et al., 2004, 2005). During the Middle Ages, new mining areas in Europe (e.g., Harz, Germany; Wales, UK) were explored and consequently European bogs were more impacted in the vicinity of those new mining areas (e.g., Kempter and Frenzel, 2000; Le Roux et al., 2004; Fig.1). A strong link between mining activity and deforestation for charcoal production is also suspected in many places in Europe (e.g., Baron et al., 2005; Monna et al., 2004; Mighall et al., 2009). Since the Industrial Revolution beginning ca. $1750 \mathrm{AD}$, a dramatic increase in atmospheric $\mathrm{Pb}$ pollution began in Europe. Bogs also bear witness to long range atmospheric transport of pollutant aerosols. For example, $\mathrm{Pb}$ from mining in the Iberian Peninsula more than 3 ka has been detected in a Swiss bog (Shotyk et al., 1998), and atmospheric $\mathrm{Pb}$ (and antimony (Sb)) contamination dating from the Roman Period has been recorded in peat from the remote Faroe Islands (Shotyk et al., 2005). After the $2^{\text {nd }}$ World War, the $\mathrm{Pb}$ isotopic signal in western Europe tends to be more spatially homogeneous due to massive $\mathrm{Pb}$ emissions from leaded gasoline combustion (e.g., De Vleeschouwer et al., 2007, 2009). However, many peat records show clearly that coal mining was also an important, and sometimes dominant (especially in eastern Europe) source of $\mathrm{Pb}$ during the second half of the $20^{\text {th }}$ century (e.g., Farmer et al., 1997; Shotyk et

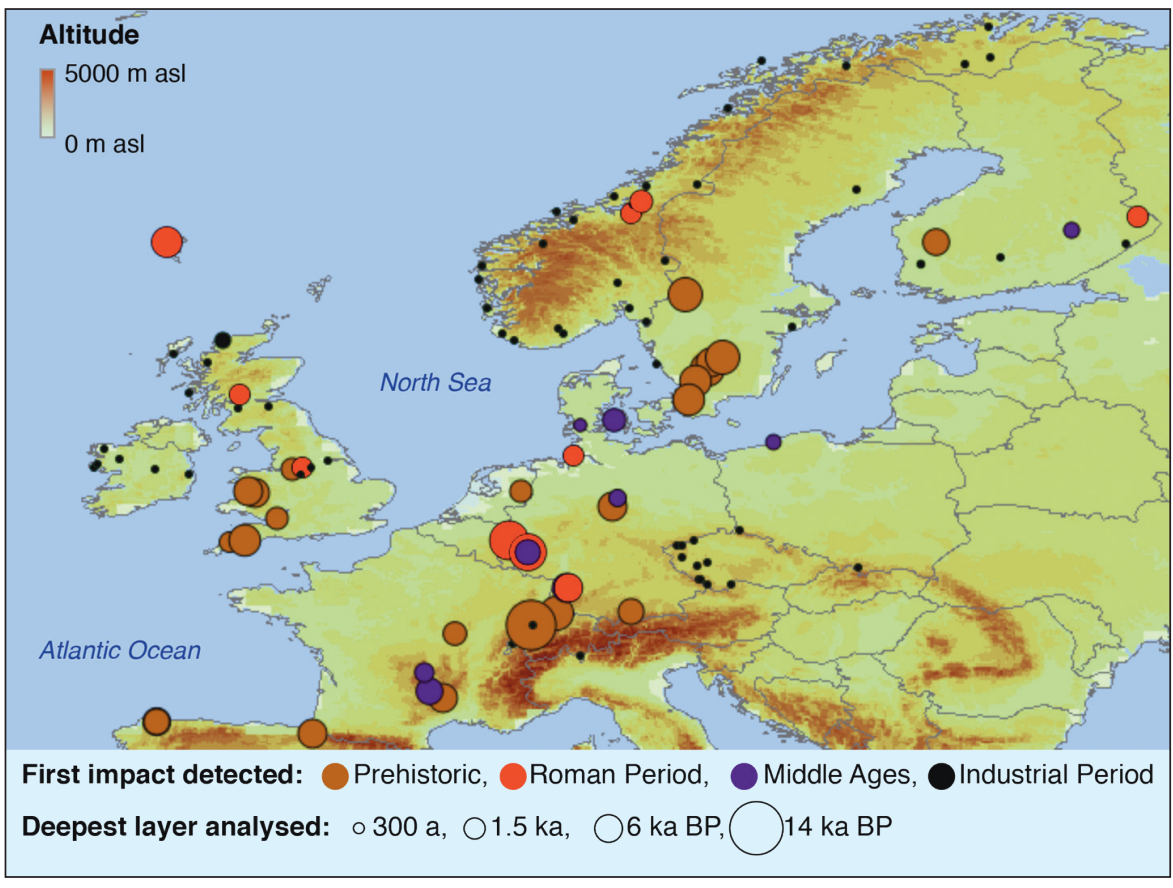

Figure 1: Map of atmospheric Pb contamination in Europe reconstructed using age-dated peat cores. Data used to produce this figure are referenced in the online reference list, indicated by an asterix. A detailed excel database is available upon request to G. Le Roux (gael.leroux@ensat.fr). Some early references, which may not be easily accessible for the reader, have been omitted. For more information, please consult: www.rzuser.uni-heidelberg. de/ i12/estandforlit.htm

al., 2003, 2005; Novak et al., 2003; De Vleeschouwer et al., 2009).

\section{High-resolution, multi-metal studies}

In Figure 2, a peat core from Lindow Bog (Manchester, UK) shows the potential of bogs as archives of paleo-pollution and archeology (Le Roux et al., 2004). Metal/titanium (Ti) ratios can be used to investigate anthropogenic deposition levels because $\mathrm{Ti}$ is a conservative element principally derived from soil erosion and not from smelting, combustion or gasoline use like metals. Therefore, by comparing the $\mathrm{Pb} / \mathrm{Ti}$ and $\mathrm{Cu} / \mathrm{Ti}$ ratios in the samples with those in the upper continental crust (i.e. the source of non-anthropogenic $\mathrm{Pb}$ and $\mathrm{Cu}$ ), it is possible to calculate the contribution of anthropogenic $\mathrm{Pb}$ and $\mathrm{Cu}$, and to derive their flux (Shotyk et al., 2000). The first Pb and Cu contamination appear ca. 1000 BC, which clearly pre-dates Roman mining activities. The timing of the ancient and medieval $\mathrm{Pb}$ pollution, as shown in Figure $2 \mathrm{a}$, is also directly related to socio-economic events (warfares, plague epidemics). The ${ }^{208} \mathrm{~Pb} /{ }^{206} \mathrm{~Pb}$ and ${ }^{206} \mathrm{~Pb} /{ }^{207} \mathrm{~Pb}$ data from the Lindow Bog indicate that English ores were the predominant sources for $\mathrm{Pb}$ atmospheric deposition in England during the pre-Roman, Roman, and medieval periods (Fig. 2b inset). This correlates well with palynological studies by Birks (1965) on the same peat profile of Lindow Bog, which indicate that different phases of vegetation clearance during the aforementioned periods are not only due to animal breeding pressure but also due to human settlements for mining activities.

Changes in atmospheric $\mathrm{Hg}$ deposition can also been found using peat cores. Thus, comparison of these three elements, derived from different sources that were worked at different times, and varying in geochemical behavior, can add value to the peat bog studies (Fig. 2). As it is true for $\mathrm{Pb}$, some small peaks of $\mathrm{Cu}$ appear in the Lindow profile before the Roman Period. Unlike $\mathrm{Pb}, \mathrm{Cu}$ is less susceptible to longrange transport and its enrichment in the peat from Lindow reflects local sources. Mercury does not show variations related to ancient metallurgy, but the clear increase beginning $0.5 \mathrm{ka}$ ago is consistent with the onset of coal burning. The differences in the timing of the $\mathrm{Pb}, \mathrm{Cu}$, and $\mathrm{Hg}$ deposition during the past five centuries remind us of the importance of multi-element studies in deciphering the changing rates and sources of atmospheric pollution (Fig. 2).

\section{Perspectives}

Until recently, the key parameters for a better understanding of heavy metal records in peat have focused upon the ombrotrophic character of the peat deposits, high-resolution multi-metal chronologies, and high quality lead isotope analyses. However, more recent studies have demonstrated that other parameters, such as the local/regional background variations, are crucial for a fully constrained interpretation and assessment of metal inventories, because the natural rates of atmo- 


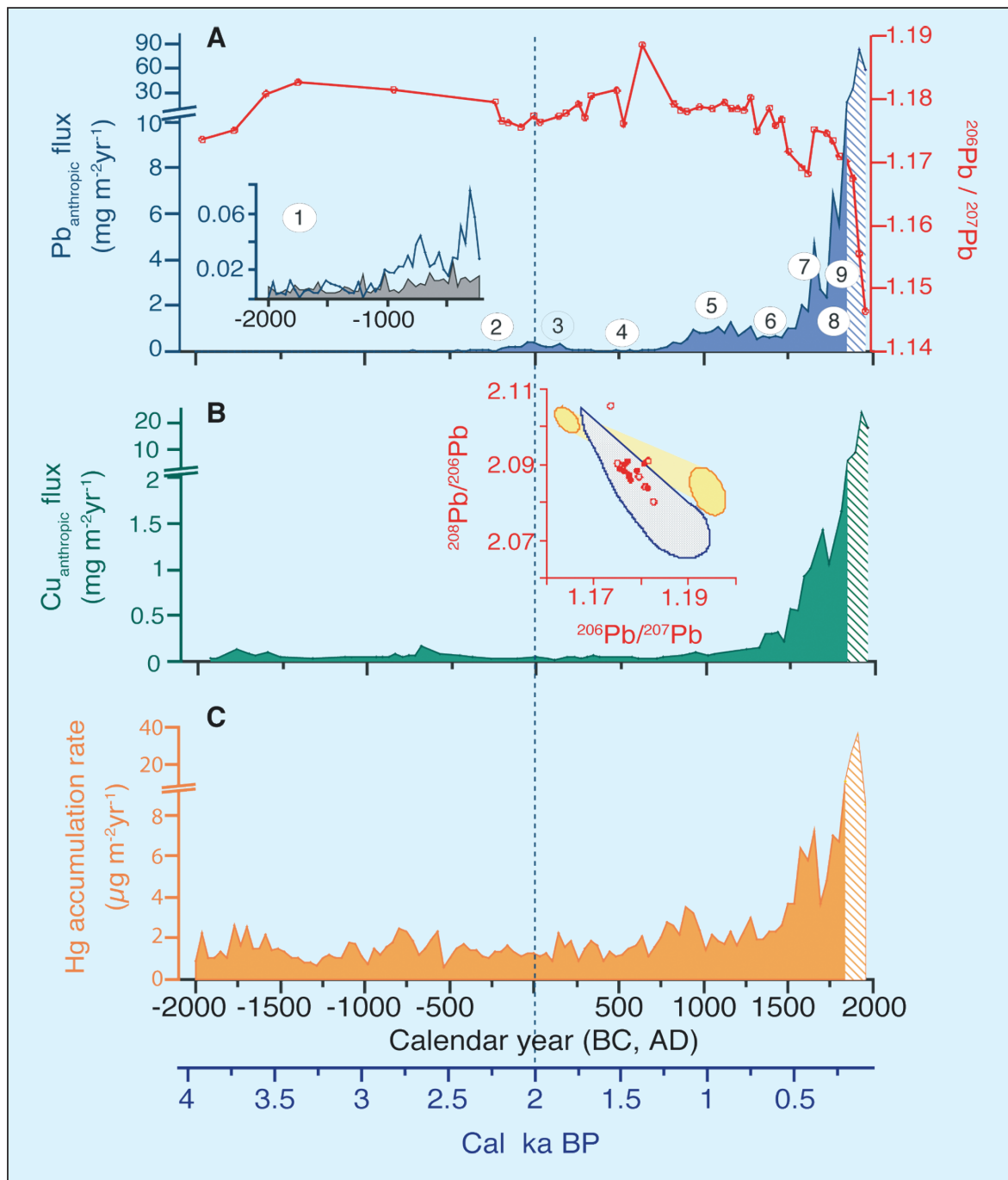

Figure 2: Lead (Pb), copper (Cu) and mercury ( $\mathrm{Hg}$ ) chronologies in Lindow Bog (UK). A) Fluxes of anthropogenic $\mathrm{Pb}$ and ${ }^{206} \mathrm{~Pb} / 207 \mathrm{~Pb}$ from $2000 \mathrm{BC}$ to $1800 \mathrm{AD}$ with focus on the pre-Roman period (Inset) to emphasize the early increase in Pb deposition at 1000 BC (from Le Roux et al., 2004). The natural estimated Pb flux is also represented (light gray). 1) Begin of use of leaded bronze in Great Britain, 2) Iron Age, 3) Roman Occupation (43 AD-410 AD), 4) Dark Ages, 5) Norman-Medieval Period, 6) Hundred Years War, plague epidemic (1349 AD), 7) German workers brought to re-organize the mines (16 th century), 8) plague epidemic (1645 AD), 9) Industrial Revolution. B) Flux of copper (green, unpublished data) and Pb three-isotope plot (inset) with peat samples (red), UKores (blue) and Spanish ores (yellow), indicating UKores as the likely source of Pb atmospheric deposition over Iron Age and Roman Occupation. C) Hg accumulation rate (unpublished data). Hatched section: recent period possibly disturbed by peat farming. spheric dust deposition may have varied considerably with climate change during the Holocene (e.g., Kylander et al., 2005; Shotyk et al., 2001). There is also a clear need for interdisciplinary studies linking paleoenvironments, geochemistry and archeology (i.e., archival records), as well as atmospheric chemistry and transport modeling. There is tremendous opportunity to employ new analytical tools for the characterization of pollutant aerosols (e.g., Scanning electron microscope, Laser Ablation inductively coupled plasma mass spectrometry) as well as to investigate other elements that have been less studied (e.g., Rare Earth Elements, Platinum Group Elements) but may provide new insights into both nutrient input by natural atmospheric dusts during pre-anthropogenic times, and human impacts on the environment.

\section{References}

Nriagu, J.0., 1983: Lead and lead poisoning in the Antiquity, John Wiley, New York.

Shotyk, W., Weiss, D., Appleby, P.G., Cheburkin, A.K., Frei, R., Gloor, M., Kramers, J.D., Reese, S. and van der Knaap, W.O., 1998: History of atmospheric lead deposition since $12,370^{14} \mathrm{C}$ yr BP recorded in a peat bog profile, Jura Mountains, Switzerland, Science, 281 $1635-1640$

Shotyk, W. and Le Roux, G., 2005: Biogeochemistry and Cycling of Lead. In: Sigel, A., et al. (Eds), Biogeochemical Cycles of the Elements. Metal lons in Biological Systems, M. Dekker, New York 43: 240275.

De Vleeschouwer, F, Fagel, N., Cheburkin, A, Pazdur, A., Sikorski, J, Mattielli, N., Renson, V., Fialkiewicz, B. and Piotrowska, N., 2009: Anthropogenic impacts in North Poland over the last 1300 years, The Science of the Total Environment, 407: 5674-5684.

Le Roux, G., Weiss, D., Grattan, J., Givelet, N., Krachler, M., Cheburkin, A., Rausch, N., Kober, B. and Shotyk, W., 2004: Identifying the sources and timing of ancient and medieval atmospheric lead pollution in England using a peat profile from Lindow bog, Manchester, Journal of Environmental Monitoring, 6: 502-510.

\section{The northern peatland carbon pool and the Holocene}

\section{carbon cycle}

David W. Beilman', G.M. MacDonald² and Z. Yu ${ }^{3}$

'Department of Geography, University of Hawai`i Mānoa, USA; beilman@hawaii.edu

Institute of the Environment, University of California, Los Angeles, USA; ${ }^{3}$ Department of Earth and Environmental Sciences, Lehigh University, Bethlehem, USA

\section{Understanding the role of peatlands in the Holocene carbon cycle will help predict the response of northern carbon stores to a changing climate.}

Northern peatlands hold a large proportion of Northern Hemisphere land carbon (equivalent to as much as $1 / 3$ of total global soil carbon) and are significant and active players in the global carbon cycle. An improved understanding of the controls and future dynamics of these carbon-rich ecosystems is possible from study of their Holocene history and previous carbon response to climate change. Peatland information relevant to Earth system dynamics includes the spatiotemporal pattern of expansion to the current $\sim 4 \times 10^{6} \mathrm{~km}^{2}$ occupied by northern peatlands, the variations in carbon accumulation at millennial and multi-centennial timescales, and the distribution of today's 270-450 Pg (1 Pg = 1 gigatonne $=10^{15} \mathrm{~g}$ ) of peatland carbon as it relates to current climate.

\section{Peatland expansion}

Recently published datasets of basal ${ }^{14} \mathrm{C}$ (radiocarbon) dates from extant peatlands indicate that northern peatlands have been sequestering atmospheric $\mathrm{CO}_{2}$ and cycling land carbon at least since the early Holocene (Figs. 1 and 2; MacDonald et al., 2006; Gorham et al., 2007; Yu et al., 2009; Korhola et al., 2010). By 8 cal ka BP, peatlands had developed extensively across the continents in the Northern Hemisphere (Fig. 2e). This rapid wetland expansion contributed to the early Holocene rise and sustained peak in $\mathrm{CH}_{4}$ concentrations after the Younger Dryas until about $8 \mathrm{cal}$ ka BP (Fig. 2c; MacDonald et al., 2006), and 


\section{F. De Vleeschouwer, G. Le Roux and W. Shotyk}

Data used in the production of figure 1 are indicated with an asterix.

*Aaby, B. and Jacobsen, J., 1979: Changes in biotic conditions and metal deposition in the last millennium as reflected in ombotrophic peat in Draved Mose, Aarbog - Danmarks Geologiske Undersoegelse, 1978: 5-43

*Aaby, B., Jacobsen, J., and Jacobsen, O.S., 1979: Lead-210 dating and lead deposition in the ombotrophic peat bog, Draved Mose, Denmark, Aarbog - Danmarks Geologiske Undersoegelse, 1978: 45-68.

*Baron, S., Lavoie, M., Ploquin, A., Carignan, J., Pulido, M. and de Beaulieu, J.-L., 2005 : Record of metal workshops in peat deposits: history and environmental impact on the Mont Lozère Massif, France, Environmental Science and Technology, 39: 5131-5140.

*Bindler, R., Brännvall, M.-L., Renberg, I., Emteryd, O. and Gripe, H., 1999: Natural Lead Concentrations in Pristine Boreal Forest Soils and Past Pollution Trends: A Reference for Critical Load Models, Environmental Science and Technology, 33: 3362-3367.

*Bindler, R., Klarqvist, M., Klaminder, J. and Förster, J., 2004: Does within-bog spatial variability of mercury and lead constrain reconstructions of absolute deposition rates from single peat records? The example of Store Mosse, Sweden, Global Biogeochemical Cycles, 18: GB 3020, doi:10.1029/2004GB002270

*Bindler, R., Renberg, I., and Klaminder, J., 2008: Bridging the gap between ancient metal pollution and contemporary biogeochemistry, Journal of Paleolimnology, 40: 755-770.

Birks H.J.B., 1965: Pollen Analytical Investigations at Holcroft Moss, Lancashire, and Lindow Moss, Cheshire, Journal of Ecology, Vol. 53, No. 2 (Jul., 1965), pp. 299-314.

*Brännvall, M.-L., Bindler, R., Emteryd, O., Nilsson, M. and Renberg, I., 1997: Stable isotope and concentration recordsof atmospheric lead pollution in peat and lake sediments in Sweden, Water, Air and Soil Pollution, 100: 243-252.

*Cloy, J.M., Farmer, J.G., Graham, M.C., MacKenzie, A.B. and Cook, G.T., 2005: A comparison of antimony and lead profiles over the past 2500 years in Flanders Moss ombrotrophic peat bog, Scotland, Journal of Environmental Monitoring, 7: 1137-1147.

*Coggins, A.M., Jennings, S.G. and Ebinghaus, R., 2006: Accumulation rates of the heavy metals lead, mercury and cadmium in ombrotrophic peatlands in the west of Ireland, Atmospheric Environment, 40: 260-278.

*De Vleeschouwer, F., Gerard, F., Goormaghtigh, C., Mattielli, N., Le Roux, G. and Fagel, N., 2007: Last two millennia atmospheric lead and heavy metals inputs in a Belgian peat bog: regional to global human impacts, The Science of the Total Environment, 377: 297310.

*De Vleeschouwer, F., Fagel, N., Cheburkin, A., Pazdur, A., Sikorski, J., Mattielli, N., Renson, V., Fialkiewicz, B. and Piotrowska, N., 2009: Anthropogenic impacts in North Poland over the last 1300 years, The Science of the Total Environment, 407: 5674-5684.

*Farmer, J.G., MacKenzie, A.B., Sugden, C.L., Edgar, P.J. and Eades, L.J., 1997: A comparison of the historical lead pollution records in peat and freshwater lake sediments from central Scotland, Water, Air and Soil Pollution, 100: 253-270.

*El-Daoushy, F. and Tolonen, K., 1984: Lead-210 and heavy metal records in dated ombrotrophic peat-hummocks from Finland, Nuclear Instruments and Methods in Physics Research B, 223: 392-399.

*Ettler, V., Navratil, T., Mihaljevic, M., Rohovec, M., Zuna, M., Sebek, O., Strnad, L. and Hojdova, M., 2008: Mercury deposition/accumulation rates in the vicinity of a lead smelter as recorded by a peat deposit, Atmospheric Environment, 42: 5968-5977.

*Ettler, V. and Mihaljevic, M., 1999: Distribution of trace elements in several ombrotrophic peat bogs in the Bohemian Massif, Rostlinna Vyroba, 45: 331-334.

*Görres, M. and Frenzel, B., 1993: The Pb, Br and Ti content in peat bogs as indicators for recent and past depositions, Naturwissenschaft, 80: 333-335.

*Görres, M. and Frenzel, B., 1997: Ash and metal concentrations in peat bogs as an indicator of anthropogenic activity. Water, Air and Soil Pollution, 100: 355-365. 
*Gilbertson, D. D., Gratten, J. P., Cressey, M., and Pyatt, F. B., 1997 : An air-pollution history of metallurgical innovation in iron- and steel-making: A geochemical archive of Sheffield, Water, Air and Soil Pollution, 100: 327-341.

*Holynska, B., Ostachowicz, B., Ostachowicz, J., Samek, L., Wachniew, P., Obidowicz, A., Wobrauschek, P., Streli, C. and Halmetschlager, G., 1998: Characterisation of ${ }^{210} \mathrm{~Pb}$ dated peat core by various X-ray fluorescence techniques, The Science of The Total Environment, 218: 239-248.

*Hutchinson, S.M. and Armitage, R.P., 2009: A Peat Profile Record of Recent Environmental Events in the South Pennines (UK), Water, Air and Soil Pollution, 199: 247-259.

*Jensen, A., 1997: Historical deposition rates of $\mathrm{Cd}, \mathrm{Cu}, \mathrm{Pb}$, and $\mathrm{Zn}$ in Norway and Sweden estimated by $\mathrm{Pb}-210$ dating and measurement of trace elements in cores of peat bogs, Water, Air and Soil Pollutio, $n$ 95: 205-220.

Jouffroy-Bapicot, I., Pulido, M., Baron, S., Galop, D., Monna, F., Lavoie, M., Petit, C., de Beaulieu, J.-L. and Richard, H. 2007: Environmental impact of early palaeometallurgy: pollen and geochemical analysis, Vegetation History and Archaeobotany, 16: 251-258.

*Kempter, H, Görres, M. and Frenzel, B., 1997: Ti and Pb concentrations in rainwater-fed bogs in Europe as indicators of past anthropogenic activities, Water, Air and Soil Pollution, 100: 367-377.

*Kempter, H. and Frenzel, B., 1999: The local nature of anthropogenic emission sources on the elemental content of nearby ombrotrophic peat bogs, Vulkaneifel, Germany, The Science of the Total Environment, 241: 117-128.

*Kempter, H. and Frenzel, B., 2000: The impact of early mining and smelting on the local tropospheric aerosol detected in ombrotrophic peat bogs in the Harz, Germany, Water Air and Soil Pollution, 121: 93-108.

*Klaminder, J., Renberg, J., Bindler, R. and Emteryd, O., 2003: Isotopic trends and background fluxes of atmospheric lead in northern Europe: Analyses of three ombrotrophic bogs from south Sweden, Global Biogeochemical Cycles, 17: 1090, doi:10.1029/2002GB001921

*Küster, H. and Rehfuess, K.-E., 1997: $\mathrm{Pb}$ and Cd Concentrations in a Southern Bavarian bog profile and the history of vegetation as recorded by pollen analysis, Water, Air and Soil Pollution, 100: 379-386.

*Kylander, M.E., Weiss, D.J. and Kober, B., 2009: Two high-resolution terrestrial records of atmospheric $\mathrm{Pb}$ deposition from New Brunswick, Canada, and Loch Laxford, Scotland, The Science of the Total Environment, 407: 1644-1657.

*Kylander, M.E., Weiss, D.J., Martinez-Cortizas, A., Spiro, B., Garcia-Sanchez, R. and Coles, B.J., 2005: Refining the pre-industrial atmospheric $\mathrm{Pb}$ isotope evolution curve in Europe using an 8000 year old peat core from NW Spain, Earth and Planetary Science Letters, 240: 467-485.

*Lee, J. and Tallis, J., 1973: Regional and historical aspects of lead pollution in Britain, Nature, 245: 216-220.

*Le Roux, G., et al., submitted: Dust input - Climate interactions through the Holocene in Central Europe, Submitted to Nature.

*Le Roux, G., Weiss, D., Grattan, J., Givelet, N., Krachler, M., Cheburkin, A., Rausch, N., Kober, B. and Shotyk, W., 2004: Identifying the sources and timing of ancient and medieval atmospheric lead pollution in England using a peat profile from Lindow bog, Manchester, Journal of Environmental Monitoring, 6: 502-510.

*Le Roux, G., Aubert, D., Stille, P., Krachler, M., Kober, B., Cheburkin, A.K., Bonani, G. and Shotyk, W., 2005: Recent atmospheric Pb deposition at a rural site in southern Germany assessed using a peat profile and snowpack, and comparison with other archives, Atmospheric Environment, 39: 6790-6801.

*Livett, E.A., Lee, J.A. and Tallis, J.H., 1979: Lead, zinc and copper analyses of British blanket peats, Journal of Ecology, 67: 865-891.

*MacKenzie, A.B., Logan, E.M., Cook, G.T. and Pulford, I.D., 1998: Distributions, inventories and isotopic composition of lead in ${ }^{210} \mathrm{~Pb}$-dated peat cores from contrasting 
biogeochemical environments: Implications for lead mobility, The Science of the Total Environment, 223: 25-35.

*Martin, M.N., Coughtrey, P.J., Ward, P., 1979: Historical aspects of heavy metal pollution in the Gordano Valley, Proceedings of the Bristol Naturalist's Society, 37:91-97.

*Martinez-Cortizas, A., Pontevedra-Pomba, X., Nóvoa Muñoz, J.C. and García-Rodeja, E., 1997: Four thousand years of atmospheric $\mathrm{Pb}, \mathrm{Cd}$, and $\mathrm{Zn}$ deposition recorded by the ombrotrophic peat bog of Penido Vello (northwestern Spain), Water, Air and Soil Pollution, 100: 387-403.

*Martinez-Cortizas, A., García-Rodeja, E., Pontevedra-Pombal, X., Nóvoa Muñoz, J., Weiss, D. and Cheburkin, A.K., 2002: Atmospheric Pb deposition in Spain during the last 4600 years recorded by two ombrotrophic peat bogs and implications for the use of peat as archives, The Science of the Total Environment, 292: 33-44.

*Mighall, T.M., Abrahams, P.W., Grattan, J.P., Hayes, D., Timberlake, S. and Forsyth, S., 2002: Geochemical evidence for atmospheric pollution derived from prehistoric copper mining at Copa Hill, Cwmystwyth, mid-Wales, UK, The Science of the Total Environment, 292: 69-80.

*Mighall, T.M., Timberlake, S., Foster, I.D.L., Krupp, E. and Singh, S., 2009: Ancient copper and lead pollution records from a raised bog complex in Central Wales, UK, Journal of Archaeological Science, 36: 1504-1515.

*Mihaljevic, M., Zuna, M., Ettler, V., Chrastny, V., Sebek, O., Strnad, L. and Kyncl, T., 2008: A comparison of tree rings and peat deposit geochemical archives in the vicinity of a lead smelter, Water, Air and Soil Pollution, 188: 311-321.

*Mihaljevic, M., Zuna, M., Ettler, V., Sebek, O., Strnad, L. and Golias, V., 2006: Lead fluxes, isotopic and concentration profiles in a peat deposit near a lead smelter (Pribram, Czech Republic), The Science of the Total Environment, 372: 334-344.

*Monna, F., Galop, D., Carozza, L., Tual, M., Beyrie, A., Marembert, F., Chateau, C., Dominik, J. and Grousset, F.E., 2004: Environmental impact of early Basque mining and smelting recorded in a high ash minerogenic peat deposit, The Science of the Total Environment, 327: 197-214.

*Nieminen, T., Ukonmaanaho, L. and Shotyk, W., 2002: Enrichment of Cu, Ni, Zn, Pb and As in an ombrotrophic peat bog near a Cu-Ni smelter in SW Finland, The Science of the Total Environment, 292: 81-89.

*Novak, M., Emmanuel, S., Vile, M.A., Erel, Y., Véron, A., Paces, T., Wieder, R.K., Vanecek, M., Stepanova, M., Brizova, E. and Hovorka, J., 2003: Origin of lead in eight Central European peat bogs determined from isotope ratios, strengths, and operation times of regional pollution sources, Environmental Science and Technology, 37: 437445.

*Novak M., Erel Y., Zemanova L., Bottrell S.H. and Adamova M., 2008: A comparison of lead pollution record in Sphagnum peat with known historical $\mathrm{Pb}$ emission rates in the British Isles and the Czech Republic, Atmospheric Environment, 42: 8997-9006.

Nriagu, J.O., 1983: Lead and lead poisoning in the Antiquity. John Wiley, New york.

Pacyna, E.G., Pacyna, J.M., Fudala, J., Strzelecka-Jastrzab, E., Hlawiczka, S., Panasiuk, D., Nitter, S., Pregger, T., Pfeiffer, H. and Friedrich, R., 2007: Current and future emissions of selected heavy metals to the atmosphere from anthropogenic sources in Europe, Atmospheric Environment, 41: 8557-8566.

Pacyna, J.M., Pacyna, E.G. and Aas, W., 2009: Changes of emissions and atmospheric deposition of mercury, lead, and cadmium, Atmospheric Environment, 43: 117-127.

*Rauch, S., Hemond, H.F., Barbante, C., Owari, M., Morrison, G.M., Peucker-Ehrenbrink, B. and Wass, U., in press: Importance of automobile emissions for platinum, palladium and rhodium deposition in the northern hemisphere, Environmental Science \& Technology.

*Rausch, N., Nieminen, T.M., Ukonmaanaho, L., Le Roux, G., Krachler, M., Cheburkin, A., Bonani, G. and Shotyk, W., 2005: Comparison of Atmospheric Deposition of Copper, Nickel, Cobalt, Zinc, and Cadmium Recorded by Finnish Peat Cores with Monitoring Data and Emission Records, Environmental Science and Technology, 39: 5989-5998. 
Renson, V., De Vleeschouwer, F., Mattielli, N., Nekrassoff, S., Streel, M. and Fagel, N., 2008: Roman road pollution assessed by elemental and lead isotopes geochemistry in East Belgium, Applied Geochemistry, 23: 3253-3266.

*Schell, W.R., Tobin, M.J., Novak, M.J.V., Wieder, R.K. and Mitchell, P.I., 1997: Deposition history of trace metals and fallout radionuclides in wetland ecosystems using ${ }^{210} \mathrm{~Pb}$ chronology, Water, Air and Soil Pollution, 100: 233-239.

*Shotyk, W., 1996: Natural and anthropogenic enrichments of As, Cu, Pb, Sb, and Zn in rainwater-dominated versus groundwater-dominated peat bog profiles, Jura Mountains, Switzerland, Water, Air and Soil Pollution, 90:375-405.

*Shotyk, W., 2002: The chronology of anthropogenic, atmospheric $\mathrm{Pb}$ deposition recorded by peat cores in three minerotrophic peat deposits from Switzerland, Science of the Total Environment, 292:19-31.

*Shotyk, W., Nesbitt, H.W. and Fyfe, W.S., 1990: The behaviour of major and trace elements in complete vertical peat profiles from three Sphagnum bogs, International Journal of Coal Geology, 15:163-190.

*Shotyk, W., Nesbitt, H.W. and Fyfe, W.S., 1992: Natural and anthropogenic enrichments of trace metals in peat profiles, International Journal of Coal Geology, 20:49-84.

*Shotyk, W., Cheburkin, A.K., Appleby, P.G., Fankhauser, A. and Kramers, J.D., 1997: Lead in three peat bog profiles, Jura Mountains, Switzerland: enrichment factors, isotopic composition, and chronology of atmospheric deposition, Water, Air and Soil Pollution, 100: $297-310$.

*Shotyk, W., Weiss, D., Appleby, P.G., Cheburkin, A.K., Frei, R., Gloor, M., Kramers, J.D., Reese, S. and van der Knaap, W.O., 1998: History of atmospheric lead deposition since $12,370{ }^{14} \mathrm{C}$ yr BP recorded in a peat bog profile, Jura Mountains, Switzerland, Science, 281: $1635-1640$.

*Shotyk, W., Blaser, P., Grünig, A. and Cheburkin, A.K., 2000: A new approach for quantifying cumulative, anthropogenic, atmospheric lead deposition using peat cores from bogs: Pb in eight Swiss peat bog profiles, Science of the Total Environment, 249: 281-295.

Shotyk, W., Weiss, D., Kramers, J.D., Frei, R., Cheburkin, A.K., Gloor, M. and Reese, S., 2001: Geochemistry of the peat bog at Etang de la Gruère, Jura Mountains, Switzerland, and its record of atmospheric $\mathrm{Pb}$ and lithogenic trace elements ( $\mathrm{Sc}, \mathrm{Ti}, \mathrm{Y}, \mathrm{Zr}$, Hf and REE) since $12,370{ }^{14} \mathrm{C}$ yr BP, Geochimica et Cosmochimica Acta, 65: 2337-2360.

*Shotyk, W., Weiss, D., Heisterkamp, M., Cheburkin, A.K. and Adams, F.C., 2002: A new peat bog record of atmospheric lead pollution in Switzerland: $\mathrm{Pb}$ concentrations, enrichment factors, isotopic composition, and organolead species, Environmental Science and Technology, 36: 3893-3900.

*Shotyk, W., Goodsite, M.E., Roos-Barraclough, F., Heinemeier, J., Frei, R., Asmund, G., Lohse, C. and Stroyer, T.H., 2003: Anthropogenic contributions to atmospheric $\mathrm{Hg}, \mathrm{Pb}$, and As deposition recorded by peat cores from Greenland and Denmark dated using the ${ }^{14}$ C AMS "bomb pulse curve", Geochimica et Cosmochimica Acta, 67: 3991-4011.

*Shotyk, W., Goodsite, M.E., Roos-Barraclough, F., Givelet, N., Le Roux, G., Weiss, D., Cheburkin, A.K., Knudsen, K., Heinemeier, J. and van Der Knaap, W.O., 2005: Accumulation rates and predominant atmospheric sources of natural and anthropogenic $\mathrm{Hg}$ and $\mathrm{Pb}$ on the Faroe Islands, Geochimica et Cosmochimica Acta, 69: 1-17.

Shotyk, W. and Le Roux, G., 2005: Biogeochemistry and Cycling of Lead. In: Sigel, A., et al. (Eds), Biogeochemical Cycles of the Elements. Metal Ions in Biological Systems, M. Dekker, New York, 43: 240-275.

*Steinnes, E., 1997: Trace element profiles in ombrogenous peat cores from Norway: evidence of long range atmospheric transport, Water, Air Soil Pollution, 100: 405-413.

*Strnad, L., Mihaljevic, M., Ettler, V., Barsova, L., Zuna, M., Sebek, O., 2008: Distribution of platinum group elements in peat deposit near a historic lead and silver mining district, Bulletin of Environmental Contamination and Toxicology, 81, 159-163. 
*Ukonmaanaho, L., Nieminen, T.M., Rausch, N. and Shotyk, W., 2004: Heavy metal and arsenic profiles in ombrogenous peat cores from four differently loaded areas in Finland, Water, Air and Soil Pollution, 158: 277-294.

*van Geel, B., Bregman, R., van der Molen, P.C., Dupont, L.M. and van Driel-Murray, C., 1989: Holocene raised bog deposits in the Netherlands as geochemical archives of prehistoric aerosols, Acta Botanica Neerlandica, 38:476-476.

*Vile, M.A., Novak, M.J., Brizova, E., Wieder, R.K. and Schell, W.R., 1995: Historical rates of atmospheric $\mathrm{Pb}$ deposition using ${ }^{210} \mathrm{~Pb}$ dated peat cores: corroboration, computation, and interpretation, Water, Air and Soil Pollution, 79: 89-106.

*Vile, M.A., Wieder, R.K. and Novak, M., 2000: 200 years of Pb deposition throughout the Czech Republic: patterns and sources, Environmental Science and Technology, 34: 1220.

*Weiss, D., Shotyk, W., Cheburkin, A.K., Gloor, M. and Reese, S., 1997: Atmospheric Pb deposition from 12,400 to ca. 2,000 BP recorded in a peat bog profile, Jura Mountains, Switzerland, Water, Air and Soil Pollution, 100: 311-324.

*Weiss, D., Shotyk, W., Appleby, P.G., Cheburkin, A.K. and Kramers, J.D., 1999:

Atmospheric $\mathrm{Pb}$ deposition since the Industrial Revolution recorded by five Swiss peat profiles: enrichment factors, fluxes, isotopic compositon, and sources, Environmental Science and Technology, 33: 1340-1352.

*Weiss, D., Shotyk, W., Boyle, E.A., Kramers, J.D., Appleby, P.G. and Cheburkin, A.K., 2002: Constraining lead sources to the North Atlantic Ocean: Recent atmospheric lead deposition recorded by two ombrotrophic peat bogs in Scotland and Eastern Canada, The Science of the Total Environment, 292: 7-18.

Wertime, T.A., 1973: The Beginnings of Metallurgy: A New Look, Science, 182: 875-887. 